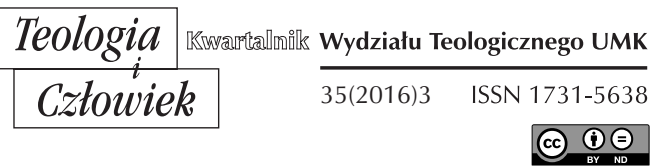

KS. TADEUSZ ZADYKOWICZ*

LUBLIN

\title{
CHRYSTOPRAKSYZM DOKTRYNY CHRZCIELNEJ
}

DOI: http://dx.doi.org/10.12775/TiCz.2016.030

Na sakrament chrztu można i należy patrzeć z różnych perspektyw: oczywiście, najpierw z perspektywy biblijnej i dogmatycznej, następnie liturgicznej i pastoralnej, a w latach takich jubileuszy, jak obchodzona właśnie 1050. rocznica chrztu Polski także pod kątem historycznym, a nawet socjologicznym i społecznym. W tym wieloaspektowym ujęciu nie może również zabraknąć spojrzenia teologicznomoralnego.

Teologia moralna od początków swego istnienia zajmowała się sakramentami, w tym sakramentem chrztu. Wystarczy wspomnieć, że pierwsze podręczniki tej dziedziny, powstałe w XVII wieku, obok analizy i aktualizacji Dekalogu, zawierały także szerokie omówienie tematyki związanej z sakramentami, a niektóre $\mathrm{z}$ nich prawie w całości były oparte na schemacie sakramentów. Ta tematyka w mniejszym lub większym stopniu dochodzi do głosu w opracowaniach teologicznomoralnych aż do naszych czasów, choć w szczegółach widoczna jest pewna różnorod-

* Ks. dr hab. Tadeusz Zadykowicz, prof. KUL. Profesor nadzwyczajny przy Katedrze Teologii Moralnej Fundamentalnej Instytutu Teologii Moralnej Katolickiego Uniwersytetu Lubelskiego Jana Pawła II (tadeuszz@kul.lublin.pl). 
ność. Jedne z nich koncentrują się na obowiązkach szafarza, inne z kolei bardziej podkreślają zadania przyjmującego. Niektóre akcentują etap przygotowania do przyjęcia i ewentualnie sam moment sprawowania, inne zaś dowartościowują konsekwencje moralne już przyjętego sakramentu.

Tym, co niezmienne w sakramentologii teologicznomoralnej, jest ukierunkowanie na praktykę, choć i tę praktykę rozumie się różnie. Specyficzny praktycyzm cechował np. teologów moralistów doby autonomizacji tej dyscypliny. Ich refleksja, najczęściej o charakterze kazuistycznym, była praktyczna w tym sensie, że miała wypełnić zadanie zawodowego instruktażu dla szafarzy sakramentów, zwłaszcza sakramentu pokuty, ale także sakramentu chrztu. Św. Paweł tymczasem zdaje się minimalizować rolę szafarza (por. Rz 6; 1Kor 1,17). W swoich Listach bardziej niż na osobie sprawującego koncentruje się on na samej naturze i na skutkach chrztu.

Pozostawiając zatem kanonistom i liturgistom zagadnienie celebracji oraz obowiązki szafarza, współczesna sakramentologia moralna stara się dowartościować praktyczne konsekwencje już przyjętego chrztu. Zgodnie z tymi tendencjami w niniejszym opracowaniu chodzi o ukierunkowanie na życiową praktykę tego, co wyraża chrzest; podkreślenie obowiązku wprowadzania w życie zasad i norm, które mają swoje źródło w darach chrztu św.; wskazanie moralnych konsekwencji wewnętrznego przekształcenia człowieka $\mathrm{w}$ tym sakramencie; skonkretyzowanie praktycznych sposobów odpowiedzi na wezwania Boga; opisanie praktycznej manifestacji „nowego życia w Chrystusie” w konkretnym działaniu.

Tak rozumiany praktyczny wymiar sakramentu chrztu określam jako „chrystopraksyzm” ${ }^{1}$. Nie oznacza on oczywiście zwyczajnego pragmatyzmu, bo ten uzależniałby prawdziwość tez od praktycznych skutków, a praktyczność, tzn. wynikające $\mathrm{z}$ tez skutki i ich użyteczność przyjmowałby za kryterium prawdy. Jeśli już łączyć (chrysto)praksyzm z pragmatyzmem, to raczej z potocznym znaczeniem tego drugiego, gdzie tak określa się postawę polegającą na realistycznej ocenie rzeczywistości,

1 Terminu tego autor użył we wcześniejszym swoim artykule w odniesieniu do teologii moralnej w ogóle, wskazując na tę jej cechę, która określa praktyczne ukierunkowanie, nastawienie na życiową praktykę, wprowadzanie w życie zasad i norm, które mają swoje ostateczne źródło w Chrystusie oraz stanowią o specyfice moralności chrześcijańskiej. Por. T. Zadykowicz, Chrystopraksyzm refleksji teologicznomoralnej, „Roczniki Teologiczne" 61 (2014) 3, s. 51. 
liczeniu się z konkretnymi możliwościami w podejmowaniu działań, które gwarantują skuteczność. Jeszcze raz jednak warto podkreślić, że bardziej odpowiednim słowem jest w omawianym kontekście „chystopraksyzm”, który oznacza ukierunkowanie na praxis całej teologii chrztu.

Wprawdzie zarzuca się niekiedy polskiej teologii moralnej zbytnie nastawienie na praxis, jednak wydaje się, że ta refleksja, w tym refleksja nad chrztem, może i powinna stawiać sobie praktyczne cele. Wynika to najpierw ze stylu pouczeń Starego i Nowego Testamentu. Charakterystycznym elementem tego stylu jest wskazywanie moralnych konsekwencji wydarzeń zbawczych (pareneza). Jest to zarazem rodzaj apelu moralnego, który ma poruszać, wzywać do działania. Drugim powodem tego ukierunkowania doktryny na praktykę jest sytuacja i mentalność współczesnego człowieka, który oddziela wiarę od życia i, choć ochrzczony, żyje "jakby Boga nie było", jakby chrzest był czczym rytuałem czy elementem tradycji. Dlatego wierność Biblii - z jednej strony - i wierność współczesnemu człowiekowi - z drugiej, każe konkretyzować sposoby odpowiedzi człowieka na wezwania Boga zawarte w sakramencie chrztu. Aby jednak sformułować charakter i szczegółowe formy tej odpowiedzi, należy najpierw, z konieczności tylko ogólnie, przedstawić doktrynę chrzcielną.

\section{ZARYS DOKTRYNY CHRZCIELNEJ}

Kluczowe elementy doktryny chrzcielnej opisuje św. Paweł, zwłaszcza w Liście do Rzymian. Cały rozdział 6 tego Listu jest poświęcony wyjaśnieniu natury i skutków sakramentu chrztu św. ${ }^{2}$ Wszystko, co Paweł powiedział $\mathrm{w}$ tym rozdziale, a także $\mathrm{w}$ wielu miejscach innych swoich Listów (por. np. Ga 3, 27-29; 1Kor 1, 10-17; 10, 1-13; 12, 12-13; Kol 2, 6-15), określa sylwetkę ochrzczonego i zarazem mówi o moralności wynikającej z chrztu ${ }^{3}$. Odwołując się do tego nauczania, Sobór Watykański II przypomina: „Wyznawcy Chrystusa, powołani przez Boga i usprawiedliwieni w Panu Jezusie nie ze względu na swe uczynki, lecz wedle

2 Por. N. Gäumann, Taufe und Ethik: Studien zu Römer 6, München 1967, s. 127.

${ }^{3}$ Por. H. Halter, Taufe und Ethos: paulinische Kriterien für das Proprium christlicher Moral, Freiburg-Basel-Wien 1977, s. 33-286. 
postanowienia i łaski Bożej, w chrzcie wiary stali się prawdziwie synami Bożymi i uczestnikami natury Bożej, a przez to rzeczywiście świętymi”" Sobór wskazuje tym samym na kilka podstawowych darów chrztu: usprawiedliwienie, synostwo Boże, uczestnictwo w Bożej naturze, świętość.

Doktrynę chrzcielną można ostatecznie sprowadzić do tematu „nowości”, którą człowiek osiąga w tym sakramencie. Szczegółowe aspekty tej nowości św. Paweł opisuje, posługując się takimi terminami, jak: „nowe stworzenie” (por. Ga 6,15; Ef 4,24; 2 Kor 5,17), „nowe życie” (Rz 6,4), „nowy człowiek” (Ef 4,24). Apostoł, mówiąc o ochrzczonych, nazywa ich również „świętymi” (por. Rz 1,7; 1Kor 1,2; 2 Kor 1,1), „dziećmi (synami) Bożymi” (Flp 2,15), „zanurzonymi w Chrystusie” (Rz 6,3; Ga 3,28), „zrośniętymi z Nim” (Rz 6,5), „oświeconymi” (Ef 5,14), „obmytymi”(Tt 3,5; 1Kor 6,11; Dz 22,16; Ef 5,26; Hbr 10,22), duchowo „obrzezanymi” (por. Kol 2,11-12). Wszystkie te określenia przedstawiają obraz przemiany, jaka dokonuje się podczas chrztu i choć odnoszą się bezpośrednio do czynności zewnętrznych, oddają nową sytuację, w jakiej znajduje się człowiek po chrzcie.

Przez chrzest człowiek zrasta się z Chrystusem w jedność do tego stopnia, że jak przeszczepiona gałązka korzysta już z soków pnia i żyje wspólnym z nim życiem (por. J 15,1-6). Zostaje uwolniony ze „starego człowieka” i przyobleka w „człowieka nowego” (por. Ga 3,27; por. także: Ef 4,22-24; Kol 3,9-10). Obmyty „w imię Jezusa Chrystusa” (por. Dz 2,38; 8,16; 10,48; 19,5; 22,16; 1Kor 1,13.15; 6,11; Ga 3,27; Rz 6,3), szczególnie się z Nim jednoczy ${ }^{5}$. O ile bowiem konsekwencją grzechu jest "dystans”, „oddalenie”, to chrzest, który skutkuje odpuszczeniem nr 40 .

${ }^{4}$ Sobór Watykański II, Konstytucja dogmatyczna o Kościele Lumen gentium,

${ }^{5}$ Wyraża to sama formuła „chrzcić kogoś w czyjeś imię” (por. Mt 28,19), która znaczy tyle, co: poświęcić komuś, oddawać w czyjąś opiekę. Oznacza ona przynależność i konsekrację, poświęcenie Bogu lub Chrystusowi. Imię oznacza w Piśmie Świętym osobę, zwłaszcza osobę Boga. Tak więc chrzest poświęca człowieka i czyni go własnością trzech osób Trójcy Świętej.

${ }^{6}$ Oddalenie od Boga jako konsekwencja grzechu sięga swymi początkami najstarszych ksiąg ST. Najbardziej przypomina ucieczkę przed Bogiem, ukrywanie się pierwszych ludzi po złamaniu zakazu Bożego. Od tego momentu zwiększał się coraz bardziej ów dystans między Bogiem a ludźmi. Co więcej, ten dystans w stosunku do Boga skutkował wzajemnym oddaleniem ludzi: pierwszych rodziców; braci Kaina i Abla, całych 
grzechów, zmniejsza ten dystans i jest nawiązaniem szczególnej więzi z Chrystusem.

Wyjątkowy charakter tej więzi polega na udziale człowieka w śmierci i zmartwychwstaniu Chrystusa. Zanurzenie się w wodzie urzeczywistnia udział w śmierci Chrystusa. Św. Paweł przyrównuje je do złożenia Chrystusa w grobie i tłumaczy, że wówczas następuje współumieranie z Chrystusem. Jak On umarł po to, by nas wybawić z grzechu, tak my umieramy w owej chwili, by zerwać wszelką łączność z grzechem (por. Rz 6,1-3). Skutkiem tego zanurzenia jest zatem odpuszczenie grzechów, śmierć starego człowieka, „człowieka zmysłowego” (por Rz 6,4). Wynurzenie zaś jest swego rodzaju współzmartwychwstaniem z Chrystusem. Symbolizuje ono wskrzeszenie do życia nadprzyrodzonego, odnowienie całego zepsutego człowieka. Nowo ochrzczony zasługuje na miano "uświęconego”, „usprawiedliwionego”, „oświeconego”, żyje w świetle, jest synem światłości.

Istotę zjednoczenia człowieka $\mathrm{z}$ Jezusem $\mathrm{w}$ Jego śmierci i zmartwychwstaniu św. Paweł oddaje terminami „nowe życie”, „nowe stworzenie” (por. Rz 6,8-10; 2Kor 5,17; Ga 6,15) lub po prostu „życie w Chrystusie" (por. Rz 6,11; 8,2). Przez obmycie wodą połączone ze słowem, tj. formułą sakramentalną, zbawcza miłość Chrystusa oczyszcza człowieka z jego grzechów i uświęca, wprowadzając go w nowe życie, tak jak nowe, chwalebne życie rozpoczął Chrystus po swym zmartwychwstaniu. Od tego momentu Chrystus „mieszka” w wiernych (por. Rz 8,10), sam „w nich żyje” (2Kor 4,10; Ga 2,20; Flp 1,21; Kol 3,4). To „nowe życie w Chrystusie” jest dziś nazywane łaską uświęcającą. Wraz z nią udzielane są cnoty teologalne. Znamienną cechą tego życia jest jego nieskończoność. Śmierć nie będzie mu zagrażać, nie będzie mieć nad nim żadnej władzy (por. Rz 6,11). Co więcej, ów dar jest przeznaczony dla wszystkich, ponieważ wszystkich - nie tylko synów Izraela, ale także tych, którzy „są daleko” (por. Dz 2,38; Ef 2,13) - Bóg powołuje do wiecznego zbawienia. Chrzest stwarza więc więzy szczególnej jedności między Chrystusem a chrześcijaninem, ale także między ochrzczonymi.

narodów - Izraela i jego wrogów. Takie oddalenie powstało nawet w łonie samego narodu wybranego, gdy nastąpił podział królestwa na dwa państwa: północne i południowe. 
Nowe życie zostaje w człowieku zainicjowane przez nowe stworzenie, które rozpoczyna w nim stan synostwa Bożego. Przez chrzest Chrystus, „nowy Człowiek”, dokonuje usynowienia wierzących. Poprzez nowe stworzenie i nowe życie człowiek staje się dzieckiem Boga w Jego Jednorodzonym Synu. Każdy chrześcijanin obmyty wodą ze świętego źródła słyszy głos, który niegdyś rozległ się nad brzegiem Jordanu: „Tyś jest mój Syn umiłowany, w Tobie mam upodobanie” (Łk 3,22), i wtedy wie, że został przyłączony do umiłowanego Syna, sam stając się synem przybranym (por. Ga 4,4-7) i bratem Chrystusa. W ten sposób - jak mówi Jan Paweł II - w dziejach każdego człowieka dopełnia się przedwieczny zamysł Ojca: „tych, których od wieków poznał, tych też przeznaczył na to, by się stali na wzór obrazu Jego Syna, aby On był pierworodnym między wielu braćmi” (Rz 8,29) 7 .

Termin „powtórne narodzenie” odniesiony do chrztu wskazuje zdaniem Ratzingera - najbardziej podstawową prawdę człowieczeństwa. Człowiekowi nie wystarcza bowiem samo narodzenie, samo biologiczne zaistnienie. Samo narodzenie bez odrodzenia byłoby nieszczęściem. Do pełnego wzrastania i życia człowiek potrzebuje sensu i miłości. Chrzest jak mówi Ratzinger - jest takim właśnie uprzedzającym darem sensu i darem miłości, która jest mocniejsza niż śmierć; która uzasadnia życie i czyni je sensownym ${ }^{8}$.

Chrzest więc nie tylko umacnia wewnętrznego człowieka (por. Ef 3,16; Rz 7,22; 2 Kor 4,16), ale czyni, stwarza "nowego człowieka” (por. Ef 2,15; Kol 3,9-10), odrodzonego w sakramencie chrztu w przeciwieństwie do człowieka zewnętrznego i starego. „Dawny”, „stary człowiek” (por. Kol 3,9; Ef 4,22) to ten, kto - bez względu na swój wiek - trwa w grzechach i jest pod władzą szatana. Wyrażenie „stary człowiek” określa postępowanie przed chrztem, które kierowane jest namiętnościami i przypomina postępowania pogan nie znających Boga (por. Ef 4,17-19). Śmierć tegoż „dawnego człowieka” podczas chrztu oznacza uniemożliwienie jego „ciału” jakiegokolwiek dominowania. „Ciało” bowiem poddawało w niewolę

7 Por. Adhortacja apostolska Christifideles laici, nr 11.

${ }^{8}$ Por. J. Ratzinger, Chrzest jako początek i drogowskaz życia chrześcijańskiego, w: J. Ratzinger, Opera omnia, t. 8, cz. 2: Kościót - znak wśród narodów. Pisma eklezjologiczne i ekumeniczne, red. K. Góźdź, M. Górecka, Lublin 2013, s. 1233. 
grzechu. Raz ukrzyżowane, traci swoją moc władczą. Kto umiera śmiercią sakramentalną $\mathrm{w}$ chrzcie św., jest usprawiedliwiony z grzechu (por. Rz 6,7). Ludzie, którzy współumierają sakramentalnie z Jezusem, definitywnie są uwolnieni od grzechu.

Chrzest, będąc powtórnym, nowym narodzeniem, dzięki któremu syn człowieka staje się synem Boga, oraz kształtując w chrześcijaninie podobieństwo do Jezusa, przekształcając go na Jego obraz, czyniąc go tym samym nowym stworzeniem, włącza go także do wspólnoty świętych. $\mathrm{Na}$ tym polega tajemnica tego sakramentu jako początku nowego życia w Chrystusie oraz w Jego jedynym Ciele, jakim jest Kościół9. Chrzest otwiera przed człowiekiem dostęp do wszystkich pozostałych sakramentów, które prowadzą życie chrześcijańskie do pełni rozwoju ${ }^{10}$.

Cała doktryna chrzcielna wskazuje jak widzialny obrzęd obmycia wodą przynosi wewnętrzne skutki. Nie tylko zapewnia on odpuszczenie grzechów, oczyszczenie (por. J 3,25), ale także - bardziej pozytywnie jest źródłem darów Ducha Świętego. Od czasu chrztu człowiek staje się „uczestnikiem Ducha Świętego" (por. 1Kor 12,13; 2Kor 1,22; Ef 1,13-14), stanowiącego porękę osiągnięcia wiekuistego szczęścia. Tenże Duch Święty zapewnia zrozumienie „wspaniałości słowa Bożego”, tj. Dobrej Nowiny o zbawieniu, zwłaszcza obietnic Bożych (por. Hbr 6,4). Można więc powiedzieć, że ochrzczony, mimo iż pozostaje sobą i żyje nadal w ciele, nie jest już podmiotem wszystkich swoich czynów. Żyje i działa w nim Chrystus. Grzech stracił nad nim prawo (por. Rz 6,11).

Podmiotem chrztu jest zawsze konkretny człowiek. Sakrament ten jednak posiada także swój wymiar wspólnotowy i wspólnototwórczy, i to nie tylko z tej racji, że - jak już wspomniano - włącza on do Kościoła. Chrzest - co warto przypomnieć w kontekście obchodzonego Jubileuszu ma moc poniekąd włączać do wspólnoty narodów. Prymas Tysiąclecia, Kardynał Wyszyński bardzo lubił mówić o „ochrzczonym narodzie”. Jan Paweł II zaś tak oceniał konsekwencje chrztu:

9 Por. Jan Paweł II, Katecheza Świadectwo życia w Chrystusie w Kościele - wspólnocie prorockiej (20.05.1992), nr 2.

${ }^{10}$ Por. Jan Paweł II, Katecheza Chrzest w Kościele - wspólnocie kapłańskiej i sakramentalnej (25.03.1992), nr 2. 
za przedziwnym zrządzeniem Bożej Opatrzności weszliśmy jako naród na arenę historii świata właśnie poprzez chrzest święty, który każdego człowieka zanurza w Chrystusa, w Jego śmierć i przez ten chrzest zostaliśmy razem z Chrystusem pogrzebani w Jego śmierci. A pogrzeb ten nie jest unicestwieniem, ale Życiem. Kto w ten sposób zostaje pogrzebany w Chrystusie, staje się wolny od grzechu i wkracza w nowe życie tak, jak Chrystus powstał z martwych dzięki chwale Ojca. W tej śmierci człowiek zostaje złączony z Chrystusem w jedno i staje się uczestnikiem Jego Zmartwychwstania (por. Rz 6,39). Tak więc dzieje naszego Narodu, bogate i trudne dzieje, narodziły się poprzez chrzest i w chrzcie narodził się nasz Naród ${ }^{11}$.

W innym zaś miejscu Papież - komentując misyjny mandat przekazany przez Chrystusa apostołom: „Dana Mi jest wszelka władza w niebie i na ziemi. Idźcie więc i nauczajcie wszystkie narody, udzielając im chrztu w imię Ojca i Syna, i Ducha Świętego. Uczcie je zachowywać wszystko, co wam przykazałem. A oto Ja jestem z wami przez wszystkie dni, aż do skończenia świata” (Mt 28,18-20) - wskazuje na wspólnotę jako podmiot chrztu: „mandat misyjny, który apostołowie podjęli, poczynając od dnia Pięćdziesiątnicy, podjęli i przekazali swoim następcom. Przez tych następców posłanie apostolskie docierało stopniowo na cały świat. I przyszedł czas przy końcu pierwszego tysiąclecia, kiedy apostołowie Chrystusa przybyli na ziemię piastowską. Wówczas Mieszko I przyjął chrzest, a to zgodnie z ówczesnym przeświadczeniem - stanowiło zarazem chrzest Polski ${ }^{12}$.

Takie określenia, jak „nowy człowiek”, „nowe stworzenie”, „nowe życie” zawierają najpierw treść ontologiczną, a dopiero potem etyczną. W określeniach tych bowiem należy dopatrywać się zasadniczej przemiany samego człowieka, a dopiero wtórnie przemiany jego postępowania. Wszczepienie w Chrystusa, szczególna łączność z Bogiem i wspólnotą ochrzczonych musi być potwierdzane w ciągu całego życia poprzez konkretną życiową praktykę, także poprzez wypełnianie konkretnych nakazów moralnych. Ta praktyka jest tylko konsekwencją przemiany dokonanej

${ }^{11}$ Jan Paweł II, Przemówienie podczas spotkania z Polonią w Brazylii (Kutyryba, 6.07.1980), nr 1 .

${ }^{12}$ Jan Paweł II, Homilia podczas Mszy św. kanonizacyjnej bł. Jadwigi Królowej (Kraków, 8.06.1997), nr 2. 
podczas wspólnej śmierci i zmartwychwstania z Chrystusem. Człowiek ochrzczony powinien inaczej patrzeć odtąd na Boga, na bliźnich i na samego siebie. Wskazują na to polecenia św. Piotra, jakie daje on w odpowiedzi na pytanie adresatów swojej mowy: „Cóż mamy czynić bracia?” (Dz 2,37). Stosownie do tych trzech kręgów odniesień można wskazać na podstawowe elementy owej praxis wynikającej z sakramentu chrztu.

\section{Il. PRAKTYCZNE KONSEKWENCJE PRZYJĘTEGO CHRZTU}

Przykładem praktycznego ukierunkowania refleksji moralnej jest jak już wspomniano - styl pouczeń Starego i Nowego Testamentu. Niekiedy pouczenia te przyjmują formę dialogu, w którym występują charakterystyczne zwroty skierowane $\mathrm{w}$ drugiej osobie i sformułowania imperatywne. Kiedy indziej są to słowa, zdania skonstruowane $\mathrm{w}$ ten sposób, by mogły być łatwiej zapamiętane. Temu praktycznemu celowi podporządkowane są także paralele, sentencje, przysłowia, rytmiczność, przywoływanie przykładów i wzorów z przeszłości ${ }^{13}$. To wszystko dotyczy także biblijnych tekstów, które mówią o chrzcie.

Z przedstawionej wyżej doktryny wynika, że podobnie jak wszystkie pozostałe sakramenty, chrzest nie może być traktowany jedynie jako pomoc w życiu moralnym, a tym mniej jako zwykły rytuał. Jego rola polega na tym, że przekształca on wewnętrznie człowieka powołanego do przymierza z Bogiem, wprowadza go w nowy obszar i w nowy wymiar $\dot{z ̇ y c i a}^{14}$. Nie oznacza to jednak jakiegoś determinizmu w życiu moralnym. Także człowiek ochrzczony może przecież nie przyjąć daru Bożego, może nie podjąć z Nim wolnej współpracy. Tymczasem prawdziwie chrześcijańskie życie moralne ma być potwierdzeniem i przedłużeniem w działaniu tego, co dokonało się na chrzcie św. To działanie dotyczy trzech podstawowych kręgów odniesień: do Boga, do drugiego człowieka i do siebie

13 Por. Zadykowicz, Chrystopraksyzm refleksji teologicznomoralnej, s. 52-53.

${ }_{14}$ Por. J. Ratzinger, Chrzest jako początek i drogowskaz życia chrześcijańskiego, s. 1232. Por. także: T. Zadykowicz, Sequela Christi et imitatio hominis. Paradygmat naśladowania we współczesnej refleksji teologicznomoralnej - źródła i perspektywy, Lublin 2011, s. 345. 
samego, które trzeba odróżniać, choć nie powinno się ich przesadnie rozdzielać.

\section{W RELACJI DO BOGA}

Praktyczne wnioski teologii, czy wręcz mistyki, chrztu zawiera zakończenie szóstego rozdziału Listu do Rzymian (w. 12-14). Potrzeba takich wniosków-napomnień jest podyktowana z jednej strony faktem niepełnej jeszcze dojrzałości moralnej każdego chrześcijanina, z drugiej zaś skłonnością do zła, jaką każdy człowiek w sobie nosi. Choć umarł już raz grzechowi i współzmartwychwstał z Chrystusem, to jednak znów może popaść w grzechy i w ten sposób obumrzeć Chrystusowi, gdyż nadal pozostaje „w ciele”, które jest grzeszne. Tymczasem obowiązkiem każdego chrześcijanina jest oddanie się całkowicie do dyspozycji Bogu. Wszystko, czym jest - całe swe ciało i duszę - powinien oddać Bogu. Potrzeba pewnej konsekwencji życiowej domaga się, by człowiek nie wracał już do grzechów, z których został wydobyty przez Chrystusa.

Podobne praktyczne wnioski można znaleźć w 3 rozdziale Listu do Kolosan, który otwiera moralną jego część. Co ciekawe jednak, zarówno część pierwsza, bardziej dogmatyczna, jak i część moralna, koncentrują się na Chrystusie, który jest głównym przedmiotem wiary i przepowiadania oraz wyłączną zasadą życia chrześcijańskiego. Ontyczna nowość tego życia nadaje mu orientację eschatologiczną: „Jeśli więc razem z Chrystusem powstaliście z martwych, szukajcie tego, co w górze, gdzie przebywa Chrystus, zasiadający po prawicy Boga. Dążcie do tego, co w górze, nie do tego, co na ziemi” (Kol 3,1-2). Punktem wyjścia tego napomnienia jest dla Apostoła ciągle przez niego podkreślany fakt zadzierzgniętej na chrzcie solidarności życia i śmierci z Chrystusem. Szukać trzeba w nowym stylu życia tego wszystkiego, co jest zgodne ze stanem, w jakim przebywa Chrystus chwalebny. W ostatecznym rozrachunku jest to szukanie Osoby, a nie normy etycznej (por. Flp 3,7-12) i takie „szukanie” tego, co w górze, jako całożyciowa postawa człowieka ochrzczonego, kontrastuje z dążeniami przyziemnymi, które charakteryzują człowieka „starego” (por. Mt 6,19-33).

Troskę o „teologalną” moralność wynikającą z chrztu widać także w 4 rozdziale Listu do Efezjan. Treści dogmatyczne ukierunkowane są 
tutaj na wskazania moralne, w myśl zasady „postępowania zgodnego z powołaniem" (por. Ef 4,1). Postępowanie to musi być kontrastowo różne od dawnego, pogańskiego stylu życia. Musi być ono życiem w miłości, której szczegółowe obowiązki rozpozna wrażliwe, czułe sumienie.

Chrzest dokonuje istotnej zmiany w osobowości człowieka i przez to nadaje on podstawową orientację życiu chrześcijańskiemu. Jest on jednak tylko początkiem spotkania, obcowania, zjednoczenia, które dopełni się w wieczności ${ }^{15}$. Życie doczesne jest tylko wstępem i wprowadzeniem, przedsmakiem tego zjednoczenia. Dlatego obowiązkiem człowieka ochrzczonego jest nieustanne odnawianie i zacieśnianie tej więź z Chrystusem, która została zadzierzgnięta w mocy Ducha Świętego podczas chrztu. W każdym $\mathrm{z}$ wiernych chrzest zainicjował tajemnicze życie Chrystusa (por. Ga 2,20), które ujawni paruzja, kiedy to chwała Chrystusa stanie się udziałem wiernych (por. 1Kor 15,42-49). Tym, którzy uwierzą i przyjmą chrzest, zostaje przedstawiona wizja czekającej nagrody (por. Mt 16,16).

Warto zauważyć, że pierwsze polecenie, jakie daje Piotr we wspomnianej już mowie z Dziejów Apostolskich, brzmi: „Nawróćcie się” (2,38). Polecenie to zobowiązuje do zmiany całego dotychczasowego sposobu myślenia, do radykalnego przestawienia się na zupełnie inne tory, co oddaje grecki czasownika $\mu \varepsilon \tau \alpha v o \varepsilon \iota v$ i jego etymologia: $\mu \varepsilon \tau \dot{\alpha}-v o v \varsigma$. Tak rozumiane nawrócenie było wymagane od początku jako warunek chrztu. Wtedy dopiero mógł nastąpić chrzest. Jednakże nieustanne nawracanie się oraz pokuta za tzw. uczynki martwe, czyli prowadzące do śmierci (por. Hbr 6,1; 9,14; Rz 13,12; Kol 3,5-8; 1J 5,16 ), winny towarzyszyć człowiekowi ochrzczonemu przez całe życie. Postawa nawrócenia jako wynikająca z sakramentu chrztu domaga się pewnego duchowego odseparowania się od ludzi złych. Każdy, kto chce prawdziwie wprowadzić w życie treść przyjętego sakramentu, musi się ratować przed wpływami „przewrotnego pokolenia” (por. Dz 2,40; Pwt 32,5; Ga 1,4; Łk 3,7; 21,23).

Jako sakrament nawrócenia, chrzest domaga się nieustannej walki z grzechem. Pomiędzy zewnętrznym a wewnętrznym człowiekiem toczy się walka (por. Rz 7,22-25), w której „nowy człowiek” otrzymuje pomoc Ducha Świętego. Każdy ochrzczony to człowiek, który obumarł grzechowi

15 Por. Jan Paweł II, Homilia podczas Mszy św. (Kraków, 10.06.1979), nr 1. 
i dlatego grzech nie powinien już mieć do niego dostępu. Współpogrzebanie, a potem współzmartwychwstanie z Chrystusem (por. Rz 6,8-10) nie jest tylko faktem historycznym, pozbawionym związków z aktualną teraźniejszością każdego chrześcijanina. Ten fakt powinien rzutować na całe nowe życie ochrzczonego, który ma zerwać wszelkie powiązania $\mathrm{z}$ grzechem. Trwanie $\mathrm{w}$ grzechu bowiem sprzeciwiałoby się podstawowym zasadom życia chrześcijan. Śmierć i zmartwychwstanie Chrystusa, w które włącza chrzest, musi oznaczać zerwanie z egoizmem i grzeszną przeszłością.

Ten aspekt negatywny doskonalenia się musi być jednak uzupełniony o aspekty bardziej pozytywne - o dojrzewanie do coraz doskonalszej, pełniejszej miłości Boga. Nowe życie wyklucza więc nie tylko pozostawanie w grzechu śmiertelnym, poddanie się nałogom i wadom, ale oznacza równocześnie początek nowego rodzaju egzystencji i dążenia do coraz pełniejszego oddania się Bogu (por. 2Kor 5,15; Rz 14,7-9; Ga 2,20). Wejście $\mathrm{w}$ to życie poprzez chrzest wyraża zatem paschalny charakter życia chrześcijańskiego i domaga się porzucenia stanu grzechu oraz nieustannego „przechodzenia” ze stanu grzechu do stanu łaski. W ten sposób ma się dokonywać ustawiczne odsłanianie tego obrazu, jaki człowiek nosi w sobie od momentu stworzenia oraz ukazywanie swoim życiem nadprzyrodzonego podobieństwa do Boga ${ }^{16}$.

Współzmartwychwstanie z Chrystusem stwarza również podstawę do nadziei życia we wspólnocie z Nim. Podczas chrztu „stary człowiek”, który popełniał grzechy, został ukrzyżowany, dzięki czemu uwolnił się od grzechu. Dar nowego życia jest więc jednocześnie zobowiązaniem. Ktoś, kto już umarł dla grzechu (por. Rz 6,2) jest jednocześnie wezwany do nieustannej walki z grzechem (por. Rz 6,12-14). Wkroczenie w nowe życie zakłada porzucenie „dawnego człowieka” (por. Rz 6,6). Wskazując na soteriologiczny wymiar chrztu, który św. Paweł wyraża słowami: „my wszyscy, którzyśmy otrzymali chrzest zanurzający w Chrystusa Jezusa,

${ }^{16}$ Por. J. Nagórny, Chrzest - nowe życie $w$ moralności Nowego Przymierza, w: Ks. Janusz Nagórny. Sakramenty z życiu moralnym chrześcijanina, red. K. Jeżyna, J. Gocko, W. Rzepa, Lublin 2011, s. 35. Por. także: T. Rogalewski, Moralny wymiar życia sakramentalnego, w: Świadek nadziei. Ks. prof. Janusz Nagórny twórca i nauczyciel teologii moralnej, red. A. Derdziuk, Lublin 2008, s. 311-312. 
zostaliśmy zanurzeni w Jego śmierć” (Rz 6,3), jednocześnie podkreśla wynikające z tego zadania: „abyśmy i my wkroczyli w nowe życie - jak Chrystus powstał z martwych" (Rz 6,3). Choć wejście w nowe życie i nowe przymierze nie jest dziełem człowieka, ale darem łaski, to domaga się ono od ochrzczonego odpowiedzi w postaci konkretnych postaw moralnych. Są one zawarte w przyrzeczeniach chrzcielnych. Ich wypełnienie sprawia, że nowa godność człowieka, która jest darem, znajduje swoje dopełnienie w „nowości” życia moralnego człowieka ochrzczonego ${ }^{17}$.

Człowiek, który trwa w grzechach, w nich widzi do pewnego stopnia cel swojej egzystencji; im służy. Gdy z nimi zerwie, w Bogu dostrzega cel swego życia: żyje dla Boga. Żyje przy tym w Chrystusie Jezusie. Zjednoczony z Chrystusem przez śmierć i zmartwychwstanie, stanowi teraz jedno ze swym Zbawcą: żyje jakby zatopiony w Chrystusie (por. Rz 6,11). Śmierć zadana grzechowi w sakramencie chrztu domaga się wytrwałego zadawania śmierci różnego rodzaju grzechom w ciągu całego życia. W Liście do Kolosan św. Paweł wymienia wykroczenia typowe dla świata pogańskiego: rozpustę, nieczystość, lubieżność, złą żądzę i chciwość, bo jak mówi - ona jest bałwochwalstwem (por. 3,5).

Nawrócenie i walka z grzechem utożsamia się z „przyoblekaniem” nowego człowieka (por. Ef 4,24). Tym terminem Paweł oddaje ideał chrześcijańskiego postępu w dziedzinie moralnej. Symbolika ta odnosi się nie tylko do praktyki cnót, ale wręcz do zjednoczenia z Chrystusem. Ochrzczony już „przyoblekł się w Chrystusa” (Ga 3,27), ale ma się wciąż w Niego przyoblekać (Rz 13,14). Zwleczenie z siebie starego człowieka domaga się nieustannego przyoblekania nowego, który wciąż się odnawia ku głębszemu poznaniu [Boga], na obraz Tego, który go stworzył (por. $3,10)$. Odzyskanie obrazu Bożego ( $\mathrm{Rdz} 1,26 n$.) - nowe stworzenie (2 Kor 5,17; Ga 6,15), zaczęło się wprawdzie z chrztem, ale odnawia się wciąż przez życie moralne godne chrześcijanina, a zakończy podczas paruzji upodobnieniem do Chrystusa, Nowego Adama - także pod względem ciała duchowego (por. 1Kor 15, 44-49). Z faktu, że chrześcijanie przeszli ze śmierci do życia (por. Kol 3,1-4), są powołani do nieustannego uśmiercania w sobie tego, co zadawałoby kłam nowemu życiu (por. Kol 3,5-17).

17 Por. A. Olczyk, Chrzest, w: Jan Paweł II. Encyklopedia nauczania moralnego, red. J. Nagórny, K. Jeżyna, Radom 2005, s. 106. 
Upodobnienie do śmierci i zmartwychwstania Chrystusa jest najpierw darem. List do Filipian wskazuje jednak również na proces tego upodabniania: „(...) w nadziei, że upodabniając się do Jego śmierci, dojdę jakoś do pełnego powstania z martwych. Nie [mówię], że już [to] osiągnąłem i już się stałem doskonałym, lecz pędzę, abym też [to] zdobył, bo i sam zostałem zdobyty przez Chrystusa Jezusa" $(3,10-12)$. Pełne zmartwychwstanie, o którym mówi autor, oznacza ostateczny kres procesu zmartwychwstania rozpoczętego na chrzcie, a kontynuowanego przez indywidualną walkę duchową ze złem. Paweł mówi tu również o „zdobywaniu” Chrystusa (por. Flp 3,12). Ten dynamizm stawania się nowym człowiekiem i przyoblekania się w Chrystusa wyraża także Pawłowa troska o to, by „znaleźć się” w Chrystusie (por. Flp 3,9). Od momentu chrztu każdy już „jest” w Chrystusie (por. Rz 6,11; 8,1; 12,5; 2Kor 5,17; Ga 3,28; Ef 1,$1 ; 2,5$ n.10; 3,6; Kol 1,2; 3,3n; 1Tes 1,1; 2,14 itd.), natomiast „znalezienie się w Nim" oznacza wysiłek człowieka i posiada ukierunkowanie eschatologiczne. Cała więc moralność wynikająca $\mathrm{z}$ sakramentu chrztu jest odpowiedzią w dialogu z Chrystusem ${ }^{18}$.

Chrzest wprowadza człowieka w przymierze z Bogiem, a tym samym zapoczątkowuje przymierze, które w ciągu życia będzie musiało być nieustannie pogłębiane, co zresztą będzie dokonywało się dzięki pozostałym sakramentom. Chrzest jest więc pierwszą odpowiedzią człowieka na Bożą inicjatywę przymierza. Z przymierzem - jak na to wskazują biblijne opisy - nierozerwalnie związane jest prawo (przykazania). Sakrament chrztu, który jest urzeczywistnieniem zawarcia przymierza, również zawiera $\mathrm{w}$ sobie prawo. To prawo zostaje wpisane $\mathrm{w}$ sercu, jego odczytanie i realizacja pozostanie zaś całożyciowym zadaniem człowieka ochrzczonego. Fundamentalnym zobowiązaniem w ramach tego prawa jest wiara i dlatego to w świetle darów sakramentu chrztu widać szczególnie moralną złość apostazji (por. Hbr 6,4-6). Obmycie wodą chrztu jest już samo w sobie wyznaniem wiary w Jezusa Chrystusa i pierwszym praktycznym następstwem wiary. Jednakże życie zgodne z darem tego

${ }_{18}$ Por. J. Nagórny, Pareneza chrzcielna - nauka płynąca z chrztu św., w: Ks. Janusz Nagórny. Sakramenty z życiu moralnym chrześcijanina, red. K. Jeżyna, J. Gocko, W. Rzepa, Lublin 2011, s. 23. 
sakramentu będzie oznaczało postawę wiary, która nie jest teorią, ale praktyką obejmującą także odniesienia człowieka do innych ludzi.

\section{W RELACJI DO BLIŹNIEGO}

Już sam obrzęd chrztu, a zwłaszcza tzw. obrzędy wyjaśniające, wskazują, że ochrzczony zostaje przyjęty do społeczności Kościoła ${ }^{19}$. Łącząc człowieka z Bogiem Ojcem, Chrystusem i Duchem Świętym, sakrament ten łączy go z innymi ludźmi - synami Bożymi i w ten sposób tworzy społeczność dzieci Bożych: nowy lud Boży - Kościół (por. Ga 3,26-29) ${ }^{20}$. Na powszechne braterstwo ochrzczonych wskazuje wspomniana mowa św. Piotra (por. Dz 2,14-41). Bóg, którego słuchacze tej mowy uważali dotąd tylko za Boga Abrahama, Jakuba, Izaaka, czyli za Boga narodu wybranego, jest w rzeczywistości Bogiem wszystkich ludzi. Bliźni, nawet ci nieobrzezani, są też bliźnimi, mają takie samo prawo do zbawienia wiecznego, jak Izraelici. Każdy człowiek, nabyty za cenę krwi Chrystusa, jest Bożą własnością, a jego ciało - to świątynia Boga Żywego. Chrzest odsłania więc wspólnotowy wymiar życia chrześcijańskiego. Stanowi on sakramentalny węzeł jedności trwający między wszystkimi przezeń odrodzonymi ${ }^{21}$.

Nowa relacja do innych ludzi, przebywanie i życie we wspólnocie Kościoła, rodzi także pewne obowiązki, które wyrażają w praktyce życie zgodne z przyjętym chrztem. Przez sakrament chrztu to cały Kościół zostaje oczyszczony przez Chrystusa „obmyciem wodą, któremu towarzyszy słowo” (Ef 5,26). Staje się on „święty i nieskalany” w swoich członkach (por. Ef 5,27). Z tego uświęcenia rodzi się dla chrześcijan - zarówno indywidualnie, jak i dla całej wspólnoty - możliwość i obowiązek życia świętego. Na tę świętość można spojrzeć od strony negatywnej i pozytywnej.

Świętość jako zadanie realizuje się najpierw poprzez nawrócenie, obejmujące także relacje z bliźnimi. Dlatego św. Paweł podkreśla, że przy-

19 Por. Sobór Watykański II, Konstytucja o liturgii świętej Sacrosanctum Concilium, nr 69.

${ }^{20}$ Por. J. Ratzinger, Chrzest jako początek i drogowskaz życia chrześcijańskiego, s. 1234 .

${ }^{21}$ Por. Sobór Watykański II, Dekret o ekumenizmie Unitatis redintegratio, nr 22. 
oblekanie się w nowego człowieka oznacza także odrzucenie wad przeciwnych szeroko pojętemu piątemu przykazaniu - różnych objawów gniewu, zapalczywości, złości, znieważania, haniebnej mowy (por. Kol 3,8). Tym, co niszczy życie społeczne i co cechuje dawnego człowieka, jest również kłamstwo (por. Ef 4,25). Jego odrzucenie jest oznaką przyoblekania się w nowego człowieka i bycia nawzajem dla siebie członkami.

Od strony pozytywnej natomiast chrzest wzywa do odkrywania i pogłębiania jedności i powszechnego braterstwa wszystkich, którzy przyjęli ten sakrament ${ }^{22}$. Ta jedność wyraża się zarówno w uczestnictwie w kulcie, jak i w głoszeniu Ewangelii: „Wierni, przez chrzest wcieleni do Kościoła, dzięki otrzymanemu znamieniu przeznaczeni są do uczestnictwa w kulcie religii chrześcijańskiej, i odrodzeni jako synowie Boży, zobowiązani są wyznawać przed ludźmi wiarę, którą otrzymali od Boga za pośrednictwem Kościoła"23.

Fakt udziału w jednym Ciele Chrystusa na płaszczyźnie moralności chrześcijańskiej oznacza wezwanie do nieustannego szukania i pogłębiania jedności. Dar chrztu św. zobowiązuje najpierw do odpowiedzialności za wspólnotę Kościoła, do przyjmowania z wiarą jego nauki, a także jego autorytetu. Ta jedność buduje się poprzez konkretne postawy i ma swoje nadprzyrodzone źródło. Wskazuje na nie św. Paweł:

A zatem zachęcam was (...) abyście postępowali (...) z całą pokorą i cichością, z cierpliwością, znosząc siebie nawzajem w miłości. Usiłujcie zachować jedność Ducha dzięki więzi, jaką jest pokój. Jedno jest Ciało i jeden Duch, bo też zostaliście wezwani do jednej nadziei, jaką daje wasze powołanie. Jeden jest Pan, jedna wiara, jeden chrzest. Jeden jest Bóg i Ojciec wszystkich, który jest i działa ponad wszystkimi, przez wszystkich i we wszystkich (Ef 4,1-6).

Jeszcze wyraźniej wezwanie do braterskiej miłości i jedności wybrzmiewa w modlitwie arcykapłańskiej Chrystusa (por. J 17,22-23). Jedność ta opiera się ostatecznie na miłości, która jednak wyraża się

22 Por. Jan Paweł II, Przemówienie podczas spotkania ekumenicznego w rezydencji Prymasa Polski (Warszawa, 8.06.1987), nr 2. Por. także: Nagórny, Pareneza chrzcielna - nauka płynąca $z$ chrztu św., s. 24.

${ }^{23}$ Sobór Watykański II, Konstytucja dogmatyczna o Kościele Lumen gentium, nr 11. 
w wielu bardziej szczegółowych postawach. Oznacza ona otwarcie się na innych, znoszenie ich słabości, szukanie tego, co służy dobru, zbudowaniu drugiego człowieka (por. Rz 15,1-3). Nie jest ona także możliwa bez postawy ofiary i cierpliwości (por. Rz 15,5-6). W sakramencie chrztu ma swoje źródło nadprzyrodzona solidarność na drogach zbawienia i jest ona znakiem odpowiedzialności za Kościół. Ta solidarność ochrzczonych wyraża się w przeżywaniu różnych spraw codzienności, ponieważ „gdy cierpi jeden członek, współcierpią wszystkie inne członki; podobnie gdy jednemu członkowi okazywane jest poszanowanie, współweselą się wszystkie członki" (1Kor 12,26).

Chrzest jest źródłem świadectwa, także osób świeckich. Na mocy tego sakramentu należą oni bowiem nie tylko do społeczności cywilnej, ale również do Chrystusa, gdyż odrodzili się w Kościele przez wiarę i przez chrzest, aby przez nowość życia i działania byli Chrystusowymi, aby w Chrystusie wszystko poddane było Bogu i by wreszcie Bóg był wszystkim we wszystkim ${ }^{24}$. Istotą tego świadectwa jest objawienie nowości życia otrzymanej na chrzcie. Upodobnienie do Chrystusa zobowiązuje do współpracy w szerzeniu i w rozwoju Jego Ciała, aby jak najprędzej doprowadzić je do pełni ${ }^{25}$. Już samo uznanie, że - bez żadnych zasług - jest się wybranym przez Boga i powołanym do godności Jego dziecka, wzywa równocześnie do postawy apostolskiej, do świadectwa wiary, do budowania świętości Kościoła i uświęcania świata. Ochrzczony, chcąc okazać w pełni wdzięczność Bogu, przyjmuje na siebie obowiązek przekazywania innym ludziom orędzia zbawienia (por. 1P 2,9). Być ochrzczonym znaczy więc wchodzić w życie Kościoła, podtrzymywać go razem z innymi i pozwalać, by nas podtrzymywał ${ }^{26}$.

Kościół wskazuje przy tym na przekazywanie orędzia zbawienia najpierw w rodzinie. To w rodzinie chrześcijańskiej, ubogaconej łaską i obowiązkami sakramentu małżeństwa, należy już od najwcześniejszego wieku uczyć dzieci zgodnie $\mathrm{z}$ wiarą otrzymaną na chrzcie poznawania

${ }^{24}$ Por. Sobór Watykański II, Dekret o działalności misyjnej Kościoła Ad gentes divinitus, nr 21.

${ }^{25}$ Por. tamże, nr 36.

${ }^{26}$ Por. Ratzinger, Chrzest jako początek i drogowskaz życia chrześcijańskiego, s. 1234 . 
i czci Boga, a także miłowania bliźniego ${ }^{27}$. Dlatego zwraca się uwagę, by nawet w samym obrzędzie chrztu uwydatnić rolę i obowiązki rodziców dziecka oraz rodziców chrzestnych ${ }^{28}$.

Zjednoczenie z Chrystusem, którego podstawą jest chrzest, zawiera także doniosłe implikacje dla podejmowania wysiłków na rzecz jedności chrześcijańskiej. Wspólny chrzest w Chrystusie jest bowiem wezwaniem dla Kościołów, aby przezwyciężały swoje podziały i w widzialny sposób zamanifestowały swoją wspólnotę ${ }^{29}$. Chrzest, jako początek zbawienia każdego człowieka, zawiera w sobie wewnętrzny dynamizm, który „całkowicie zmierza do osiągnięcia pełni życia w Chrystusie" ${ }^{\text {"30 }}$. Ma zatem prowadzić do pełnego wyznania wiary, do całkowitego wcielenia w zgodną z wolą Chrystusa instytucję zbawienia, wreszcie do pełnego wszczepienia w eucharystyczną wspólnotę. Przed ochrzczonymi stoi więc zadanie przezwyciężania przeszkód na drodze do tej wspólnoty i wspólnego wzrastania w jedności, jaką Chrystus na początku obdarzył swój Kościół, który jest jeden.

\section{W RELACJI DO SIEBIE}

Powrót do korzeni i do początku, do chrztu, umożliwia człowiekowi coraz lepsze zrozumienie siebie samego i innych, a w tym świetle coraz lepsze budowanie własnej historii doczesnej i historii zbawienia ${ }^{31}$. Człowiek jest istotą rozumną i wolną, jest świadomym i odpowiedzialnym podmiotem. Może i powinien osobistym wysiłkiem myśli docierać do prawdy. Może i powinien wybierać i rozstrzygać. Tę właściwą wielkość człowieka jeszcze bardziej uświadamia chrzest: „ «Zanurzenie w wodzie»,

${ }^{27}$ Por. Sobór Watykański II, Deklaracja o wychowaniu chrześcijańskim Gravissimum educationis, nr 3.

${ }^{28}$ Por. Sobór Watykański II, Konstytucja o liturgii świętej Sacrosanctum Concilium, nr 67.

${ }^{29}$ Por. Komisja „Wiara i Ustrój” Światowej Rady Kościołów, Chrzest. Dokument z Limy (1982), nr 6.

${ }^{30}$ Por. Sobór Watykański II, Dekret o ekumenizmie Unitatis redintegratio, nr 22.

${ }^{31}$ Por. Jan Paweł II, Przemówienie podczas spotkania z Polonią w Brazylii (Kutyryba, 6.07.1980), nr 1 . 
które jest znakiem wezwania do uczestnictwa w życiu Trójcy Przenajświętszej, jest równocześnie niezastąpionym sprawdzianem godności każdego człowieka. Już samo to wezwanie o niej świadczy. Człowiek musi posiadać niezwykłą godność, skoro został wezwany do uczestnictwa w życiu Boga samego" 32 .

Przez chrzest człowiek uczestniczy w pięknie, którym Chrystus go obdarzył, według słów świętego Pawła: „Chrystus umiłował Kościół i wydał za niego samego siebie, aby go uświęcić, oczyściwszy obmyciem wodą, któremu towarzyszy słowo, aby osobiście stawić przed sobą Kościół jako chwalebny, nie mający skazy czy zmarszczki, czy czegoś podobnego, lecz aby był święty i nieskalany" (Ef 5,25-27). To piękno jednak musi być nieustannie potwierdzane $\mathrm{w}$ działaniu.

Poprzez sakrament chrztu - jak to już zostało podkreślone - człowiek zostaje prawdziwie wcielony w Chrystusa ukrzyżowanego i uwielbionego i odradza się ku uczestnictwu w życiu Bożym. Jednakże to wcielenie samo przez się jest jedynie zaczątkiem, ponieważ zmierza do osiągnięcia pełni życia w Chrystusie. Zatem chrzest ma prowadzić człowieka do pełnego wyznawania wiary, do całkowitego wcielenia w zgodną z wolą Chrystusa instytucję zbawienia, wreszcie do pełnego wszczepienia w eucharystyczną wspólnotę $e^{33}$.

Otrzymana na chrzcie pieczęć, zwana znamieniem (gr. sfragís), (por. Ef 1,13; por. także: 4,30; 2Kor 1,22) jest znakiem przynależności ${ }^{34}$. Ochrzczony jako osoba staje się własnością Boga i Chrystusa (por. Ap 7,1-8) i w tej przynależności należy upatrywać najgłębsze źródło obowiązku realizacji powołania do osobistej świętości. Dzięki zjednoczeniu z Bogiem ochrzczony może uczynić ze swojej egzystencji kapłańską ofiarę złączoną z ofiarą Chrystusa (por. Rz 12,1; 1P 2,4-5). Praktyczne sposoby realizacji tego powołania są wielorakie. Udział w życiu kultycznym i sakramentalnym, a także prowadzenie takiego stylu życia, który jest naśladowaniem Chrystusa (por. Hbr 12,1-3), upodabnianiem się do Niego, walką z grzechem, winno towarzyszyć ochrzczonemu przez całe życie.

32 Jan Paweł II, Homilia podczas Mszy św. (Kraków, 10.06.1979), nr 2.

33 Por. Sobór Watykański II, Dekret o ekumenizmie Unitatis redintegratio, nr 22.

${ }^{34}$ Odbicie pieczęci na niewolniku, zwierzęciu lub martwym przedmiocie było w starożytności znakiem przynależności do właściciela pieczęci. 
Moralność chrztu jest więc ukierunkowana także na dobrze rozumianą samorealizację. Choć ostatecznym celem tej moralności jest zbawienie, to zakłada ona także pomnażanie cnót, a więc w pewnym sensie doskonalenie się w wymiarze doczesnym. Rozpoczynając w chrześcijaninie nowe życie, sakrament chrztu wzywa do nieustannego doskonalenia siebie, dążenia do doskonałości ${ }^{35}$. To właśnie z chrztem związane jest podstawowe wezwanie moralne, jakim jest prowadzenie świętego życia. Można oczywiście wskazywać na szereg zobowiązań szczegółowych, do których wzywa ten sakrament, ale wydaje się że doskonalenie to zakłada najpierw nieustanną walkę z grzechem i z tym wszystkim, co staje na drodze ku pełni w Chrystusie (por. Rz 6,1-14; Kol 2,11-13), choć się do tego nie ogranicza.

Doktryna chrzcielna, a więc to, co stanowi treść tego sakramentu, implikuje pewne zadania, których pominięcie i niewypełnienie sprowadziłoby go do aktu kultu, który nie posiada istotnego wpływu na codzienne wybory. Z kolei codzienne wybory, niemające silnego oparcia w doktrynie, stałyby się aktami posłuszeństwa oderwanymi od całego systemu norm i przepisów. Doktryna ta zatem musi posiadać swój wymiar praktyczny, co oznacza, że pozwala ona odczytać samą istotę moralności chrześcijańskiej, która polega na współdziałaniu z Bogiem, oraz konkretne, specyficzne zobowiązania, jakie zaciąga człowiek przyjmujący ten sakrament. Ponieważ chrzest jest obdarowaniem „nowym życiem w Chrystusie”, życie na miarę tego daru można nazwać chrystopraksyzmem, który oznacza ostatecznie praktyczne wcielanie w życie norm i zasad moralnych, mających swoje źródło w doktrynie chrzcielnej.

W refleksji naukowej taki chrystopraksyzm będzie oznaczał jakiś typ projekcji teorii na życiowe doświadczenie, ukazywanie zależności etosu od wiary, ukazywanie w jaki sposób życiowa „praktyka” ma swój fundament w kondycji człowieka stworzonego i odkupionego ${ }^{36}$. W przypadku sakramentu chrztu będzie to np. stwierdzenie, że dar nowego

${ }^{35}$ Por. Nagórny, Pareneza chrzcielna - nauka płynaca z chrztu św., s. 27. Por. także: A. Derdziuk, Teologia moralna w stużbie wiary Kościoła, Lublin 2010, s. 271.

${ }^{36}$ Por. Zadykowicz, Chrystopraksyzm refleksji teologicznomoralnej, s. 62. 
życia jest wezwaniem do nieustannego doskonalenia siebie. Dar dziecięctwa Bożego zobowiązuje do przyjęcia postawy dziecka, którą najlepiej wyrażają zaufanie i posłuszeństwo. Dokonujące się zaś w sakramencie chrztu włączenie do wspólnoty eklezjalnej oznacza przyjęcie na siebie odpowiedzialności za wspólnotę Kościoła, ale także twórczą obecność w różnych wspólnotach naturalnych. To wszystko zaś ma być ożywiane wdzięcznością i radością jako tymi postawami, które są niejako pierwszą reakcją człowieka obdarowanego.

Ostatecznie chrystopraksyzm jest naturalną konsekwencją chrystocentryzmu moralności chrześcijańskiej. Chrystus jest wszystkim: normą, rzeczywistością, prawem i życiem, jednością. Jego Osoba i życie winno stać się także kryterium chrześcijańskiego działania ${ }^{37}$. Dlatego zarówno samo sprawowanie chrztu, jak i różnego rodzaju celebracje nawiązujące do tego sakramentu (Wigilia Paschalna, rocznice chrztu itp.) powinny przypominać to wszystko, co dokonuje się podczas tego sakramentu (doktryna), a co jednocześnie inicjuje drogę życia moralnego. Powinna to być okazja do udzielania praktycznych pouczeń dotyczących postępowania zgodnego z przyjętym chrztem. Te zaś staną się w pełni zrozumiałe, jeśli osadzi się je w samej treści tego sakramentu.

Streszczenie. Teologicznomoralna refleksja nad sakramentem chrztu stawia sobie za cel ukierunkowanie na życiową praktykę tego, co wyraża chrzest; podkreśla obowiązek wprowadzania w życie zasad i norm, które mają swoje źródło w darach chrztu św.; wskazuje moralne konsekwencje wewnętrznego przekształcenia człowieka w tym sakramencie. Refleksja ta ma zatem charakter praktyczny. Ponieważ jej przedmiotem jest ostatecznie praktyka „nowego życia w Chrystusie”, posiada ona cechę, którą można nazwać chrystopraksyzmem. Tak rozumiany chrystopraksyzm wynika bezpośrednio z doktryny chrzcielnej i obejmuje całe życie człowieka oraz wszystkie kręgi jego odniesień (do Boga, do innych ludzi, do samego siebie). Do postaw moralnych, które szczególnie należy wiązać z chrztem należą: wdzięczność, nawrócenie, wiara, miłość, jedność.

Słowa kluczowe: chrzest; chrystopraksyzm; sakramentologia moralna.

Abstract. Christopraxis of baptismal doctrine. The moral theological reflection on the sacrament of baptism aims to focus on the life practice of the meaning of baptism; it underlines the responsibility of the implementation of principles and standards

\footnotetext{
37 Por. tamże.
} 
that have their source in the gifts of baptism; it indicates the moral consequences of the internal transformation of man in the sacrament. The nature of the reflection is therefore practical. Because its subject is ultimately the practice of a "new life in Christ", it has a feature that can be called christopraxis. Thus understood, christopraxis stems directly from the baptismal doctrine and covers the whole human life and all his circles of reference (i.e. to God, to others, to himself). Moral attitudes, which are particularly associated with baptism include: gratitude, repentance, faith, love, unity.

Keywords: baptism; christopraxis; moral sacramentology. 